\title{
ANALISIS KOMPONEN ASAM LEMAK DAN MINERAL (Ca, Mg, Fe, Zn) IKAN KAKAP PUTIH (Lates calcalifer)
}

\author{
Nazudin 1 , Hernina wattimena ${ }^{2}$ \\ ${ }^{1}$ Program Studi Pendidikan Kimia, Jurusan MIPA FKIP Unpatti
}

Diterima 20 April 2019/Disetujui 23 Mei 2019

\begin{abstract}
The analysis of fatty acid component and mineral composition ( $\mathrm{Ca}, \mathrm{Mg}, \mathrm{Fe}, \mathrm{Zn}$ ) of white snapper fish (Lates calclifer) had been done. Flesh of white snapper fish (Lates calclifer) was extracted with petroleum benzene and obtained $6.06 \%$ of oil. Oil fish was transesterified by using $\mathrm{BF}_{3}-$ methanol $20 \%$. The result of transesterification was analysed by using and GC-MC obtained nine fatty acid component, those were myristic acid methyl ester 5.94\%; pentadecanoic acid methyl ester 1,58\%; palmitoleic acid methyl ester 8.73; palmi acid methyl ester 17.69; Margarate acid methyl ester $1.96 \%$; linoleic acid methyl ester $1.56 \%$; oleic acid methyl ester $15.83 \%$; streaic acid methyl ester $10.41 \%$; aracidonic acid methyl ester $5.26 \%$. the result of minerals composition analysis used atom absorption spectrophotometer (ASS) showed that the content of calcium (Ca), Magnesium (Mg), ferrum (Fe), zinc (Zn), were $51,1 \mathrm{mg} / \mathrm{kg} ; 574 \mathrm{mg} / \mathrm{kg} ; 65 \mathrm{mg} / \mathrm{kg}$; and 10,8 mg/kg, respectively. Oil of white snapper fish (Lates calcalifer) contains esensial fatty acid that is benefit to humans body. In the another hand, it also contains mineral content which is enough that it is goof to be consumend by the people.
\end{abstract}

Key words: Fatty acid, Mineral, Lates calcalifer

\section{ABSTRAK}

Telah dilakukan analisis komponen asam lemak dan mineral ( $\mathrm{Ca}, \mathrm{Mg}$, Fe, $\mathrm{Zn}$ ) pada ikan kakap putih (Lates calcalifer) diekstraksi dengan petroleum benzen diperoleh minyak sebesar $6,06 \%$. Minyak ditransesterifikasi menggunakan katalis $\mathrm{BF}_{3} 20 \%$ - methanol. Hasil transesfterifikasi dianalisis menggunakan GS-MS dan diperoleh 9 komponen asam lemak yaitu : (1) metil ester asam miristat 5,94\%; (2) metil ester asam pentadekanoat 1,58\%; (3) metil ester asam palmitoleat 8,73\%; (4) metil ester asam palmitat 17,69\%; (5) metil ester asam margarat 1,96\%; (6) metil ester asam linoat 1,56\%; (7) metil ester asam oleat 15,83\%; (8) metil ester asam stearate 10,41\%; (9) metil ester asam arakidonat 5,26\%;. Hasil analisis kandungan mineral menggunakan spektrofotometer serapan atom (SSA) menunjukan bahwa kandungan kalsium (CA), magnesium (Mg), besi (Fe), zink (Zn) berturut-turut adalah 51,1 mg/kg; 65mg/kg; dan 10,8 mg/kg. Minyak ikan kakap putih (Lates calcalifer) mengandung asam lemak esensial yang bermanfaat bagi kesehatan tubuh manusia. Selain asam lemak juga terkandung mineral yang cukup sehingga sangat baik dikonsumsi oleh masyarakat.

Kata kunci: Lates calcalifer, Asam lemak, Mineral

\section{PENDAHULUAN}

Indonesia merupakan Negara maritim terbesar di dunia sehingga sector perikanan memegang peranan penting dalam penyedian lapangan kerja, sumber pendapatan nelayan dan sumber devisa Negara. Selain itu produk perikanan juga merupakan sumber lemak hewani yang dibutuhkan oleh manusia.

Pemanfaatan sumber daya laut seperti ikan, crustacean, dan moluska sebagai bahan makanan tidak terlepas dari nilai nutrisi yang terkandung di dalamnya. Lemak merupakan zat makanan yang penting untuk menjaga kesehatan tubuh manusia. Selain itu juga merupakan yang lebih efektif 
dibandingkan dengan karbohidrat dan protein. Lemak digunakan untuk melindungi organ-organ tubuh dan juga berfungsi sebagai sumber dan pelarut bagi vitamin-vitamin $\mathrm{A}, \mathrm{D}, \mathrm{E}$ dan $\mathrm{K}$ (Winarno, 2002).

Asam lemak penyusun tubuh terdiri dari dua yaitu asam lemak jenuh dan asam lemak tak jenuh. Asam lemak jenuh terutama ditemukan dalam makanan yang berasal dari hewan seperti daging sapi, daging babi, dan produk-produk lemak yang dikonsumsi tiap hari. Lemak jenuh berkaitan dengan resiko meningkatnya kolesterol darah, obesitas dan timbulnya penyakit jantung atau strok (Andarwulan, dkk, 2011).

Kandungan asam lemak pada ikan $1-20 \%$ berupa lemak yang mudah dicerna serta langsung dapat digunakan oleh jaringan tubuh. Kandungan lemaknya sebagian besar adalah asam lemak tak jenuh omega-3-nya yaitu : DHA (docosahekseanoic acid), dan EPA (eikosapentainoic acid). Selain DHA dan EPA minyak ikan juga mengandung asam lemak omega-3 yang lain (LNA/linoleneanoic acid dan DPA/docopentaenoic acid) dan asam lemak omega-6 (LA/linolenic acid dan AA/arachidonic acid) yang dibutuhkan untuk pertumbuhan dan dapat membantu menurunkan kadar. kolesterol darah (Winarno, 1999). Asam lemak takjenuh rantai panjang omega-3 diketahui banyak terdapat dalam lemak atau minyak ikan dan hewan laut lainnya. Secara kimiawi lemak adalah ester dari asam lemak dan alkohol (Winarno, 1994).

Pertumbuhan sel otak manusia sangat bergantung dari kadar omega-3 dan omega- 6 secara cukup dari janin sampai balita. Oleh karena berbagai manfaat asam lemak omega-3 dan omega- 6 inilah yang mendorong perusahaan susu formula menambahkan asam lemak omega-3 dan omega6 ke dalam produknya. Produk susu pertumbuhan dengan kadar DHA, EPA, LA dan AA yang tinggi dijual di pasaran berkisar 20-30 gram tiap seratus gram bubuk. Namun, karena harganya yang mahal sehingga tidak dapat dijangkau oleh masyarakat ekonomi lemah, maka diharapkan ikan menjadi alternatif sumber DHA dan EPA karena ikan merupakan penyumbang utama asam lemak takjenuh (DHA dan EPA) dalam bahan pangan (Soenardi, 2000).

Ikan kakap putih (Lates calcalifer) adalah ikan demersal karnivora yang hidup di pantai dan estuaria dan juga terdapat di perairan Maluku yang merupakan salah satu ikan laut ekonomis penting karena rasa dagingnya yang lezat. Akan tetapi masyarakat belum mengetahui kandungan gizi yang terkandung di dalamnya seperti asam lemak dan mineral yang dapat dibandingkan dengan kelezatan dan tingginya harga ekonomis dari ikan tersebut sehingga perlu dilakukan analisis.

Pupela (2012) telah melakukan analisis komponen asam lemak pada ikan parang-parang (Trichiurus lepturus) dan ikan perak (Mene maculata) dengan menggunakan katalis asam BFgMetanol pada tahap transesterifikasi dan metil ester yang diperoleh dianalisis menggunakan GC-MS (Gas ChromatographyMass Spectroscopy). Hasil penelitiannya menunjukkan bahwa pada T richiurus lepturus dan Mene maculata terkandung tiga kompohen asam lemak tidak jenuh dari tujuh komponen asam lemak, secara berturut-turut adalah asam oleat (12,27\% dan $6,82 \%)$; asam pahnitoleat $(4,82 \%$ dan 2,65\%); dan asam-5,8,11,14eikosatetraenoat (1,44\% dan 1,29\%).

Ikan laut tidak hanya mengandung asam lemak tetapi juga mengandung banyak mineral seperti kalsium (Ca), magnesium (Mg), besi ( $\mathrm{Fe})$, dan zink ( $\mathrm{Zn})$. Oleh karena itu, ikan juga merupakan sumber utama mineral yang dibutuhkan tubuh. Pada umumnya mineral seperti $\mathrm{Ca}, \mathrm{Mg}, \mathrm{Fe}$ dan $\mathrm{Zn}$, berpertan penting dalam reaksi biokimia, misalnya $\mathrm{Ca}$ untuk pertumbuhan tulang dan gigi, $\mathrm{Fe}$ berperan dalam produksi sel darah merah, sedangkan Mg merupakan faktor penting dalam aktivitas enzim. Zn juga terlibat dalam metabolisme karbohidrat, protein, dan lemak. Sumber mineral paling baik berasal dari makanan hewani karena makanan nabati jumlah ketersediaan biologisnya lebih sedikit. Hal ini disebabkan oleh adanya bahan pengikat mineral seperti serat yang dapat mengganggu penyerapan mineral (Santoso, 2009).

Latumahina (2011) telah melakukan analisis kandungan $\mathrm{Ca}, \mathrm{Mg}, \mathrm{Fe}$, dan $\mathrm{Zn}$ pada ikan julung (Hiperhampus balinensis) dengan menggunakan SSA (Spektrofotometer Serapan Atom) dan diperoleh kandungan $\mathrm{Ca}, \mathrm{Mg}$, Fe, dan $\mathrm{Zn}$ berturut-turut adalah 746,00 mg/kg, 656,55 mg/kg, 23,66 $\mathrm{mg} / \mathrm{kg}, 40,17 \mathrm{mg} / \mathrm{kg}$. 
Pada penelitian ini, dilakukan analisis komponen asam lemak dan mineral ( $\mathrm{Ca}, \mathrm{Mg}, \mathrm{Fe}$ dan $\mathrm{Zn}$ ) pada ikan kakap putih (Lates calcalifer). Analisis komponen asam lemak menggunakan katalis asam BF 3-metanol pada tahap transesteriflkasi dan metil ester asam lemak dianalisis menggunakan GCMS sedangkan analisis kandungan mineral digunakan metode SSA. Dengan adanya informasi tentang kandungan asam lemak dan mineral maka diharapkan dari ikan kakap putih (Lates calcalifer) dapat dimanfaatkan untuk memenuhi kebutuhan akan asam lemak esensial dan mineral.

\section{METODE PENELITIAN}

\section{Alat - alat}

Hairdryer, Desikator, Oven (Memert), Peralatan ekstraksi soxhletasi (Pyrex), GC-MS 2010 plus (Zhimadzu), Spektrometer serapan Atom (AA 6300, Zhimadzu), Hotplate (Ciramec 2), 8. Neraca Analitik (Adam Equipment) 9. Labu alas bulat (Pyrex), Blender, Pompa vakum, Beberapa peralatan gelas lain seperti gelas kimia, erlemeyer, corong pisah, pipet tetes, dan gelas ukur.

\section{Bahan}

Bahan-bahan yang digunakan dalam penelitian ini adalah : 1. Daging ikan kakap putih (Lates calcalifer) 2. Akuades 3. Asam klorida ( $\mathrm{HCl}$ ) pekat p.a (E. Merck) 4. Asam nitrat (HNOs) pekat pa (E. Merck) _ 5. Petroleum benzen p.a (E. Merck) 6. Boron tritlourida $20^{\circ} 0$ dalam methanol (E. Merck) 7. n-heksana p.a (E. Merck) 8. Na2804 anhidrous p.a (E. Merck) 9. Kapas 10. Kertas saring Whatman No. 42 III.4.

\section{Preparasi Sampel}

Ikan dibersihkan dari sisiknya, dibelah, di ambil dagingnya, dipoting kecil-kecil dikringkan dengan menggunakan hairdryer, selanjutnya dikringkan di dalam oven pada suhu $47^{\circ} \mathrm{C}$ sampai beratnya konstan. Setelah beratnya konstan daging ikan menggunakan blender.

\section{Isolasi Minyak}

Sebanyak 79,9395 g daging ikan kakap putih kering yang telah halus dibungkus dengan kertas saring, bagian atas ditutup dengan kapas dan dimasukkan ke dalam tabung soxhlet, selanjutnya dimasukkan petroleum benzen sebanyak 6000 dari volume labu ekstraksi. Ekstraksi dilakukan sampai campuran menjadi bening. Ekstrak yang diperoleh kemudian dituangkan ke dalam erlenmeyer yang diketahui beratnya, diuapkan pelarutnya, ditutup dengan kertas saring, kemudian ditimbang.

\section{Transesterifikasi}

Sebanyak $4,8408 \mathrm{~g}$ minyak ikan dan $20 \mathrm{~mL}$ boron triflourida $20^{\circ} \mathrm{o}$ dalam metanol dimasukkan ke dalam labu alas bulat 100 . $\mathrm{mL}$ yang dilengkapi dengan pengaduk magnet dan pendingin bola, kemudian campuran diaduk dan direflulgs selama 90 menit di atas penangas air pada suhu $65^{\circ} \mathrm{C}$. Hasil refluks yang telah dingin ditambahkan $25 \mathrm{~mL}$ akuades kemudian dimasukkan ke dalam corong pisah selanjutnya ditambahkan $20 \mathrm{~mL}$ n-heksana, setelah itu diekstraksi. Setelah terbentuk 2 lapisan, lapisan bawah yang mengandung gliserol dipisahkan dan lapisan atas (metil ester) diekstrak dengan $10 \mathrm{~mL}$-heksana sebanyak dua kali. Lapisan atas dicuci dengan akuades hingga pH-nya netral. Selanjutnya lapisan metil ester ditambahkan dengan Na2804 anhidrous. Campuran disaring dan pelarut diuapkan pada suhu kamar selanjutnya hasil campuran metil ester telah siap dianalisis dengan menggunakan GC-MS.

\section{Analisis Mineral}

Penentuan Kandungan Ca, Fe, Zn, dan Mg dalam Daging Ikan Kakap Putih dengan SSA 
Daging ikan kakap putih (Lates calcalifer) yang telah halus ditimbang sebanyak $10 \mathrm{~g}$ kemudian dimasukan kedalam erlenmeyer yang telah diketahui beratnya Ke dalam erlenmeyer ditambahkan $10 \mathrm{~mL}$ HNOg. Erlenmeyer dipanaskan perlahan-lahan sampai berwarna gelap. Selanjutnya ditambahkan $2 \mathrm{~mL} \mathrm{HNO}_{3}$ dan pemanasan dilanjutkan sampai larutan lebih gelap lagi. Penambahan HN03 dilanjutkan sambil dipanaskan selama 10 menit sampai campuran menjadi bening. Sampel didinginkan kemudian ditambahkan $10 \mathrm{~mL} \mathrm{HCl}$ dan dipanaskan kembali sampai bening. Larutan didinginkan kemudian disaring dan diencerkan sampai volume $100 \mathrm{~mL}$ dan diukur absorbansinya menggunakan SSA.

\section{HASIL PENELITIAN}

\section{Kadar Air ikan kakap putih (Lates calcalifer)}

\section{Kadar Air}

Penentuan kadar air dilakukan dengan metode Thermogravimetri (pengeringan) agar sampel yang digunakan benar-benar bebas dari kandungan air. Kadar air dihitung berdasarkan selisih berat sebelum dan sesudah pengeringan. Hasil penelitian menunjukkan bahwa daging ikan kakap putih (Lates calcalifer) mengandung air sebesar 67,0500 (Lampiran 1). Kandungan air yang cukup tinggi ini perlu dihilangkan karena kandungan air yang terdapat dalam sampel menyebabkan minyak sukar diekstraksi dengan pelarut nonpolar karena pelarut sukar masuk ke dalam jaringan yang basah dan menyebabkan pelarut jenuh dengan air sehingga kurang efisien untuk proses ekstraksi (Sudarmadji, dkk, 2007).

\section{Analisis Komponen Asam Lemak pada Ikan Kakap Putih (Lates calcalifer)}

Analisis komponen asam lemak pada ikan kakap putih (Lates calcalifer) dilakukan setelah tahap isolasi minyak. Sebanyak $79,94 \mathrm{~g}$ daging ikan kering diekstraksi menggunakan pelarut petrolium benzen dan diperoleh minyak ikan sebanyak 4,84 g (6,0600) (Lampiran 1). Selanjutnya, 4,84 g minyak ikan ditransesterifikasi menggunakan katalis BF3-metanol $20^{\circ} \mathrm{O}$ untuk memperoleh _ metil ester asam lemak. Metil ester asam lemak yang diperoleh selanjutnya dianalisis menggunakan GCMS (Gas Chromatography-Mass Spectrometer) dan diperoleh 19 puncak kromatogram, setelah dilakukan identivikasi terhadap spectrum massa dari puncak-puncak yang dominan maka terdaapat 9 senyawa metil ester yang dapat diindentivikasi seperti yang disajikan pada Tabel 3.

\begin{tabular}{|c|c|c|c|c|}
\hline Tabel & \multicolumn{4}{|c|}{$\begin{array}{l}\text { 3. Hasil Analisis Metil Ester Asam Lemak pada Ikan Kakap Putih } \\
\text { (Lates calcali er) den:an Katalis Asam Men:: nakan GC-MS }\end{array}$} \\
\hline No. & $\begin{array}{l}\text { Waktu Retensi } \\
\text { menit) }\end{array}$ & $\begin{array}{l}\text { Senyawa metil } \\
\text { ester }\end{array}$ & $\underset{\substack{\mathbf{o}_{0} \\
\text { Persen Komposisi }}}{ }$ & Keterangan \\
\hline 1 & 12,475 & Metil Miristat & 5,94 & Asam lemak jenuh \\
\hline 2 & 15,217 & $\begin{array}{c}\text { Metil } \\
\text { Pentadekanoat }\end{array}$ & 1,58 & Asam lemak jenuh \\
\hline 3 & 17,384 & $\begin{array}{l}\text { Metil } \\
\text { Palmitoleat }\end{array}$ & 8,73 & $\begin{array}{l}\text { Asam lemak tak jenuh } \\
\text { tunggal }\end{array}$ \\
\hline 4 & 17,990 & Metil Palmitat & 17,69 & Asam lemak jenuh \\
\hline 5 & 20,450 & $\begin{array}{c}\text { Metil } \\
\text { Heptadekanoat }\end{array}$ & 1,96 & Asam lemak jenuh \\
\hline 6 & 22,150 & Metil Linoleat & 1,56 & $\begin{array}{l}\text { Asam lemak tak jenuh } \\
\text { jamak }\end{array}$ \\
\hline 7 & 22,356 & Metil Oleat & 15,83 & $\begin{array}{l}\text { Asam lemak tak jenuh } \\
\text { tunggal }\end{array}$ \\
\hline 8 & 22,929 & Metil Stearat & 10,41 & Asam lemak jenuh \\
\hline 9 & 25,996 & $\begin{array}{c}\text { Metil } \\
\text { Arakidonat }\end{array}$ & 5,26 & $\begin{array}{l}\text { Asam lemak tak jenuh } \\
\text { jamak }\end{array}$ \\
\hline
\end{tabular}


Untuk Hasil analisis yang diperoleh pada minyak ikan kakap putih (Lates calcalg'fer) mengandung lima asam lemak jenuh (SFA) yaitu asam miristat, asam pentadekanoat, asam heptadekanoat, asam palmitat, dan asam stearat. SFA tidak berguna bagi kesehatan karena menyebabkan rdarah lengket pada dinding saluran darah sehingga darah mudah menggumpal. Selain itu, SFA mampu merusak dinding saluran darah (arteri) sehingga menjadi kaku dan menyempit. Gejala tersebut disebut arteriocslerosz's dan biasanya berlangsung lambat, yakni memerlukan beberapa tahun atau bahkan puluhan tahun. Konsumsi lemak jenuh berlebihan dapat menyebabkan dan mempercepat proses arteriocslerosis (Almatsier, 2002).

Ikan kakap putih (Lates calcalifer) juga mengandung asam lemak tak jenuh tunggal (MUFA) yaitu asam palmitoleat dan asam oleat yang lebih dikenal sebagai asam lemak omega-9. MUFA memiliki daya perlindungan yang mampu menurunkan LDL-kolesterol darah, meningkatkan HDLkolesterol yang lebih besar dibanding asam lemak omega-3 dan asam lemak omega-6, dan lebih stabil dibandingkan dengan PUFA. Hal ini dapat dilihat dari masyarakat yang hidup di kawasan Mediteranian yang jarang ditemukan penderita jantung koroner karena tingginya konsumsi asam lemak omega-9 dan asamlemak omega-3. Sedangkan di kawasan barat (Amerika Serikat dan Eropa) konsumsi asam lemaknya memiliki perbandingan $10: 1$ (asam lemak omega-6 : asam lemak omega3), yang dianggap tidak sehat (Qauliyah, 2005 dalam Pupela, 2012).

Asam linoleat dan asam arakidonat merupakan asam lemak tak jenuh jamak (PUFA) yang terkandung di dalam ikan kakap putih (Lates calcalifer). PUFA baik untuk tubuh dan sangat berguna bagi kesehatan karena mampu memperbaiki dinding arteri (pembuluh darah) yang telah rusak oleh asam lemak jenuh (Winarno, 1999). Selain itu, PUFA merupakan asam lemak esensial karena tidak dapat disintesis di dalam tubuh tetapi keberadaannya sangat dibutuhkan karena asam lemak tersebut dapat menurunkan kadar kolesterol darah sehingga dapat mencegah terjadinya arteriocslerosis, mencegah penyakit jantung koroner dan menurunkan tekanan darah tinggi bagi penderita hipertensi (Holub dan Holub, 2004).

Ikan kakap putih (Lates calcalifer) mengandung empat komponen asam lemak tak jenuh yaitu asam palmitoleat, asam oleat, asam linoleat, dan asam arakidonat yang sangat berguna bagi kesehatan. Dengan demikian, Ikan kakap putih (Latex calcalifer) dapat dimanfaatkan untuk melengkapi kebutuhan gizi masyarakat akan asam lemak.

\section{Kandungan Mineral Kalsium (Ca), Mangensium (Mg), Besi (Fe) dan Zink ( $\mathrm{Zn}$ ) pada Ikan Kakap Putih (Lates calcalifer)}

Analisis kandungan mineral pada ikan kakap putih (Lates calcalifer) dilakukan melalui destruksi basah dengan $\mathrm{HNO} 3$ dan $\mathrm{HCl}$ untuk mengoksidasi komponen organik. Secara umum lebih dianjurkan dengan tujuan kecepatan waktu pengerjaan, penggunaan temperatur pada tingkat rendah dan menurunkan kemungkinan kehilangan unsur yang dianalisis (Andarwulan, dkk, 2011).

Hasil analisis kandungan mineral $\mathrm{Ca}, \mathrm{Mg}$, Fe, dan $\mathrm{Zn}$ pada ikan kakap putih (Lates calcalifer) dengan menggunakan SSA disajikan pada Tabel 4.

Tabel 4. Hasil Analisis Kandungan Mineral Ca, Mg, Fe, dan Zn pada Ikan Kakao Putih (Lates calcalifer) dengan menggunakan SSA.

\begin{tabular}{cc}
\hline Mineral & Kadar $(\mathrm{mg} / \mathrm{kg})$ \\
\hline $\mathrm{Ca}$ & 51,10 \\
$\mathrm{Mg}$ & 475 \\
$\mathrm{Fe}$ & 65 \\
$\mathrm{Zn}$ & 10,80
\end{tabular}


Tabel 4 menunjukan kandungan kalsium (Ca) pada ikan kakap putih yaitu sebesar $51,10 \mathrm{mg} / \mathrm{kg}$. Mineral kalisum pada ikan sangat dipengaruhi oleh faktor makanan dan lingkungan (habitat). Ikan kakap putih (Lates calcalifer) memangsa ikan kecil, crustacea, cumi-cumi, dan molusca yang memiliki kandungan kalsium yang tinggi (Jubeq, 2010)

\section{KESIMPULAN}

Berdasarkan hasil penelitian yang dilakukan maka dapat disimpulkan sebagai berikut.

Minyak ikan kakap putih (Lates calcalifer) mengandung 9 jenis komponen asam lemak yaitu asam miristat 5,94 00; asam pentadekanoat 1,5800; asam palmitoleat 8,7300; asam palmitat 17,690 0 ; asam heptadekanoat 1,9600; asam linoleat 1,560 0; asam oleat 15,8300; asam stearat 10,4100; dan asam arakidonat 5,2600 .

Kandungan mineral kalsium (Ca), magnesium (Mg), besi (Fe), dan zink ( $\mathrm{Zn}$ ) pada ikan kakap putih (Lates calcalifer) berturut-turut adalah $51,10 \mathrm{mg} / \mathrm{kg}, 475 \mathrm{mg} / \mathrm{kg}, 65 \mathrm{mg} / \mathrm{kg}$ dan 10,80 mg/kg.

\section{DAFTAR PUSTAKA}

Adnan, M., 1997, Teknik Kromatograji Untuk Analisis Bahan Makanan, Andi, Yogyakarta.

Almatsier, S., 2002, Prinsip Dasar Ilmu Gizi. Gramedia Pustaka Utama : Jakarta

Andarwulan, N., Kusnandar.F., Herawati, D., 2011, Analisisa Pangan, Dian Rakyat, Jakarta

Anggorodi, R, 1994, Ilmu Makanan Ternak Umum, Gramedia Pustaka Utama, Jakarta.

Anonimus, 1990, Perkembangan Rekayasa Teknologi Pembenihan Ikan Kakap Putih (Lates Carcalifer, Bloch) di Balai Budidaya Laut lampung. Ditjen Perikanan: Lampung

Astawan, M., 2009, Seimbangkan Omega 6 dan Omega 3, diakses dari hlm ://c bermed.cbn.net.id/cbortl/c bermed/detailasux?x=Nutn'tion\& -c bermed $006522 . P a d a$ tanggal 15 november 2010.

Brown,H.W., 1995, Organic Chemistry, Saunder College Publishing, Philadelphia, New York.

Darrnono, 1995, Logam dalam Sistem Biologi Makhluk Hidup Universitas Indonesia Press: Jakarta

Day, A.Jr., \& Underwood, A.L., 1999, Analisis Kimia Kuantitatif, diterjemahkan oleh Sopyan I., Edisi Keenam, Erlangga, Jakarta.

Efendi, 2003, Telaah Kualitas Air, Kanisius : Yogyakarta

Fessenden, R., \& Fessenden, J. 1986, Kimia Organik, diterjemahkan oleh Pudjaatmaka H., Jilid 2, Edisi keenam, Erlangga, Jakarta.

Fitriani, A., 2006, Profil Asam Lemak Omega-3 dalam Hati lkan Manyung

(Arius Thalassinus) yang Mengalami Pemanasan Pendahuluan (Blancing), Tugas Akhir 11, Jurusan Kimia, FMIPA UNNES, Semarang.

Graham T W, 1991 , Trace Element Deficiencies In Cattle. Vet Clin, N, Am.

Gritter, R.J., Bobbit, J.M., \& Schwarting, A.E., 1991, Pengantar Kromatografi, ITB, Bandung.

Hardjono, 198 7, Biologi dan Budidaya Kakap Putih (Lates Calcarifer) INFISH Manual Seri no.47 . Ditjen Perikanan_Intemasional Development Research Centre : Jakarta

Harmita, 2000, Analisis F isiko Kimia, Spektrometer serapan Atom. Universitas Indonesia : Jakarta

Hikmah, M.N., \&Zuliyana, 2010, Pembuatan Metil Ester (Biodisel) Dari Minyak Dedak dan Metanol Dengan Proses Esterijikasi dan Transesten'jikasi, Skripsi, Jurusan Teknik Kimia, Fakultas Teknik, Universitas Diponegoro, Semarang

Holub, D.J., \& Holub, B.J., 2004, Omega-3 Fatty Acids from Fish Oils and Cardiovaskular Disease, Journal of Molecular Cell Biochemistry, 263,217-225.

Hu, RB., \& Willet, W.C., 2002, Optimal Diets for Prevention of Coronary Heart Disease, The Journal of the American Medical Association, 288,2569-2578. 
Jubeq, 2010, memahami Kalsium Karang, diakses dari http: //id. Shvoong. com/medicine-and hea1th/matritus/2 1 92629-memahamikalsium-karang/\#xzzifMigsyze, pada tanggal 7 juni 2012.

Latumahina, L., 2011, Analisis Kandungan Mineral (Ca, Mg, Fe, Zn ) dan Asam Lemak pada Ikan Julung (Hmerhampus balinensis), Skripsi, Program Studi Pendidikan Kimia, FKIP UNPATT I, Ambon

Lehninger, A.L., 1982, Dasar-dasar Biokimi, diterjemahkan oleh: Thenawidjaya M., Jilid 1, Erlangga: Jakarta

Mohamad, H., 2003, Omega-3 Modal Untuk Kecerdasan, diskses dari Muchtadi, T. R,2008, Asam Lemak Omega 9 dan Manfaatnya Bagi Kesehatan. Universitas Indonesia-Pres, Jakarta

Mulja, M., 1994, Perkembangan Instrumentasi Kromatrogaji Gas, UI Press, Jakarta.

Nilasari, A., 2004, Isolasi Minyak Biji kelumpan g (Sterculia foetida) Dengan Menggunakan Berbagai Macam Pelarut, Tugas Akhir II, FMIPA UNNES, Semarang

Poedjiadi, A., 2007, Dasar-Dasar Biokimia, UI Press, Jakarta.

Puls R, 1994, Mineral Levels and Animal Health Diagnostic Data. Second Edition Sherpa International Clearbrook, BC.

Pupela, RW., 2012, Komposisi Asam Lemak pada Ikan Parang-Parang ( Trichiuruss lepturus) dan Ikan Perak (Mene maculate) Skripsi, Program Studi Pendidikan Kimia, FKIP UNPATTI, Ambon.

etno, DP., 2002., Isolasi dan Identifikasi Asam Lemak dari Minyak Ikan

Lemuru (Sardinella Lougiceps) dengan Metode GC-MS, Skripsi, FMIPA Universitas Negeri Malang, Malang.

Santoso, w., 2009, Komposisi Mineral Makro dan Mikro Daging Ikan Gurami (Ousphronemus gouramy )Pada Berbagai Waktu Pemeliharaan, Skripsi, Fakultas Perikanan dan IImu Kelautan, IPB, Bogor.

Silverstein, R M., \& Webster, F. hX., 1998, Spectrometic Identification of Organic Compounds, 6h Edition, John Wiley and Sons Inc., New York.

Sitorus, M., 2009, Spektoskopi-Elusidasi Struktur Molekul Organik, Graha Ilmu, Yogyakarta.

Soenardi I, 2008, Ikan Laut Hidangan Prima Masa Depan. PT Kompas Media Nusantara: Jakarta

Underwood and Day, 1999, Analisis Kimia Kuantitatif Edisi keenam. Erlangga: Jakarta

Voet, D., Voet, I.G., \& Pratt, CW., 2006, Fundamentals ofBiochemistry-Life at moleculer Level, $2^{\text {nd }}$ Edition, John Wiley and sons Inc., New York

Winarno, F.G., 2002. Kimia Pangan dan Gizi, edisi kesembilan. Gramedia Pustaka Utama Jakarta 